\title{
ASSESSING THE RATE OF CHILD MAINTENANCE (FINANCIAL SUPPORT) FROM A SHARIAH PERSPECTIVE The Case of Malaysia ${ }^{1}$
}

\author{
Bahiyah Ahmad; Raihanah Hj. Azahari; Asmak Ab Rahman; \\ Mazni Abdul Wahab \\ University of Malaya, Malaysia \\ email:babiyah_api@um.edu.my
}

\section{Abstract}

Shariah mandates the criteria of kifäyah and ma'rüf in assessing maintenance for wives and children; however, these criteria currently require assesment and evaluation as maintenance is mostly influenced by society's practices and by socioeconomic status. Consequently, Malaysia's Islamic Family Law (Federal Territory) Act 1984 presribes that the maintenance assesment for wives and children must be based on the means (ma'rūf) and needs (kifāyah) of the parties. However, this provision is too general and there is no clear explanation of what constitutes these criteria for the parties. This provision has troubled some parties as it leaves the determination of the maintenance rate to a judge's discretion regarding both criteria. This study, with a methodology of content analysis and in-depth interviews, determines an assessment formula for both criteria in assessing child maintenance.

[Hukum Islam mensyaratkan dua kriteria dalam pemberian nafkah istri dan anak yaitu ma'rūf dan kifāyah. Namun kriteria tersebut saat ini perlu ditinjau dan evaluasi lagi sesuai dengan praktik masyarakat serta

1 The study was conducted with grant and monetary support from the Ministry of Higher Education, Malaysia, under the Fundamental Research Grant Scheme (FRGS:FP023/2011A). 
Bahiyah Ahmad et al.

keadaan social ekonomi saat ini. Seperti yang terdapat dalam Hukum Perundangan Keluarga Islam Malaysia tahun 1984 yang menyatakan bahwa ma'rūf dan kifāyah menjadi syarat utama pemberian nafkah istri dan anak. Bagaimanapun penjelasan kriteria tersebut masib terlalu umum dan kurang jelas. Hal ini juga menyisakan beberapa persoalan akibat keputusan pengadilan yang mendasarkan pada kedua kriteria tersebut. Dengan menggunakan pendekatan analisis isi dan wawancara mendalam, kajian ini menguatkan penilaian kedua kriteria tersebut.]

Keywords: child maintenance, financial support, assessment, ma'rüf, kifäyah

\section{A. Introduction}

The maintenance of children in Islam is guaranteed in the verses of the Qur'an, the hadith of the Prophet Muhammad (SAW) and is confirm in shariah. Allah (SWT) orders a man who is the father of children to give maintenance to his wife and children for their food, drinking and clothing by ma'rüf (Upon the father is the mothers' provision and their clothing according to what is acceptable). ${ }^{2}$ In other verses, Allah (SWT) orders husbands and ex-husbands to give their wives, or wives in the iddah period, and his children a proper place to live for which the man must pay (Lodge them [in a section] of where you dwell out of your means and do not harm them in order to oppress them). ${ }^{3}$ In the hadith of Hindun, she complains to the Prophet Muhammad (SAW) that her husband, Abu Sufyan, was being stingy by not spending enough on her and her children. The Prophet (SAW) gave Hindun permission for she and her son to take (in ma'rüf) from her husband's property enough (kifäyah) to support their standard of living. This is based on a hadith recorded in the book of Sabih al-Bukhariand Muslim in which the Prophet Muhammad (SAW) said, "Khu§hi ma yakfiki wa waladaki bil ma'rüf" (Take what is enough for you and your child in an acceptable way). ${ }^{4}$ Additionally,

2 Qur'an, 2: 233.

3 Qur'an, 65: 6.

4 Narrated by al-Bukhārī, Kitab al-Nafaqāt, Bab Khidmah al-Rajul fi Ahlihī, no. 5049, and Muslim, Kitab al-'Aqİiyah, Bab Qadiyyah Hindun, no. 1714, See Muhammad bin Ismā̄îl al-Bukhārī Abū 'Abd Allāh, "Șaḥịh al-Bukhārì”, in al-Jami" al-Sabih al-Mukhtasar, 
in the farewell sermon of the Prophet (SAW), Jabir reported that, in the Prophet's message on his last pilgrimage, he dealt at length regarding women, part of which stated: "If they (your wives) abide by your right, then to them belongs the right to be fed and clothed in acceptable way (ma'rüf)." "Thus shariah gives guidelines to determine that the maintenance of wives and children should be based on the criteria of that which is sufficient (kifäyah) and acceptable (ma'ruf).

The Islamic Family Law (Federal Territories) Act 1984 of Malaysia provides that the maintenance of one's wife and child be assessed according to the means (capabilities) and needs of the parties:

In determining the amount of any maintenance to be paid, the Court shall base its assessment primarily on the means and needs of the parties, regardless of the proportion the maintenance bears to the income of the person against whom the order is made (author's emphasis). ${ }^{6}$

The 'means' is actually a consideration of the criterion of ma'ruf and the 'needs of parties is a consideration of the criterion of kifayah as discussed by fuqaba. ${ }^{7}$ However, in interpreting what is considered in both criteria (kifayah and the ma'ruf), this study finds that there is no explanation or details regarding any manual or guidelines to be used by judges to measure both criteria for the parties involved as determined by shariah. ${ }^{8}$

Due to the generality of these provisions and the lack of detailed guidelines, Malaysian judges use their discretion in interpreting the provisions in accordance with their understanding of the assessment methods in order to determine maintenance. In Sarah binti Hamalo vs

vol. 5, 3rd edition, ed. by Muștafā Dīb al-Bughā (Beirut: Dar ibn Kathir, 1987), p. 2052; Muslim bin Ḥajjāj Abū al-Hussain al-Qusyairi al-Naisābūrī, Șahịh Muslim, vol. 2, ed. by Muḥammad Fu'ad 'Abd al-Bāqī (Beirut: Dar Ihya al-Turath al-'Arabi, 2012), p. 1338.

${ }^{5}$ Narrated by Muslim, Kitab al-Hāj, Bab Hujjah al-Nabī (SAW), no.1218. See al-Naisābūrī, Șah̄ị̣ Muslim, 2: 890.

${ }^{6}$ Islamic Family Law (Federal Territory), sec. 61, http://www2.esyariah.gov.my/ esyariah/mal/portalv1/enakmen2011/Eng_act_lib.nsf/b3ac9c218c8efdc44825683100 22d8b3/86ecb41a724cb751482569810025f16a?OpenDocument, accessed 14 Apr 2020.

7 Bahiyah Ahmad, "Penentuan Kriteria Kifayah dan Ma'ruf Nafkah Isteri dan Anak di Malaysia", PhD. Dissertation (Kuala Lumpur: University of Malaya, 2015), pp. 67-96.

8 This was confirmed earlier in an interview with the judge in August-December 2012. 
Adam Stanislaw Naglik@ Adam bin Abdullah in the High Court of Shah Alam in 2018, the plaintiff applied for interim maintenance of RM16,000 for the first child to further their studies at the University of Leiden in the Netherlands, amounting to RM8700 per month, and for the second child, amounting RM4505 per month. The application was based on the plaintiff's salary of RM27000; after deducting his expenses of RM18000, the balance was RM9000. The court considered that a child should be given what is he or she needs at the level of his or her daruriyyat and hajiyat, which is needed for living, compared to tabsiniyyat, which is the completed thing in life. The court also found that the amount requested by the plaintiff was excessive and unreasonable. Because the plaintiff did not detail the daruriyyat and hajiyat items needed by the children, the court favoured an offer from the plaintiff to support both children for RM8000 per month. The references justifying the reasonableness of the amount are absent from the written case report but the court believed that RM8000 was reasonable for the needs of the children for that time and according to what the respondent could afford. ${ }^{9}$ There was thus no detailed explanation of how the amount of RM8000 per month for both children was determined in the judgement and whether the criterion of kifayah (the needs of the children) was considered.

In Siti Norzatulshima bt Abdullah vs Abdul Aziz bin Mat Hassan in the Shariah Appeal Court in 2015, the plaintiff had appealed a decision of the Shariah High Court which determined a rate of the maintenance for her children contrary to their ages, needs and current expenses. The decision ordered the respondent (the father) of the children to pay the first child, aged 19 and who was in college, RM700 per month. The second and third children, aged 15 and 14 and were in secondary school, were maintained at RM600 per month. The plaintiff was not satisfied with the judgment and claimed that the judges did not estimated the amount of maintenance according the children's needs, ages and current expenses. As a result, the Appeal Court determined the actual amount needed by the children in accordance with their lifestyle in the town of Shah Alam, Selangor, where the plaintiff and her children live. According to the judge, the amount should be thus for the children: breakfast at RM5, lunch at

9 "Sarah binti Hamzah vs Adam Stanislaw Naglik @ Adam bin Abdullah", Jurnal Hukum, vol. 46, no. 1 (2018), pp. 145-50. 
RM8, dinner at RM8 and supper at RM5, amounting to RM26 per day; RM100 and RM200 were added for the children for other needs such as education, toiletries and clothes. Thus, the oldest child should receive RM800 for her maintenance and the other children should get RM600 as they only live with the plaintiff for 16 days every month. ${ }^{10}$ The decision of the Shariah Appeal Court detailed food and drink expenses but the remaining monthly expenses of RM100-RM200 for education, toiletries and clothes can still be seen as a lump sum amount awarded by the court. However, any amount without an explanation of the details will lead to a misinterpretation of the judgment.

In considering the criteria of kifäyah, judges seem to more favourably regard the condition of the payer (father or husband) compared with the needs of the wife and children. The 2010 case of Sri Utama Dewi Kasman lwn Abu Bakar bin Abdullab ${ }^{11}$ discussed this. Although in this case the judge took into account the basic needs of the wife and child, the husband's ability to pay still affected the judgement. If a man declares himself poor or if the plaintiff (who claims the maintenance) is unable to produce evidence related to the claim, the judge will reduce the maintenance at the request of the defendant (payer). ${ }^{12}$ It may be that the rate demanded by the plaintiff is only sufficient for survival. Efforts to ensure that basic needs are satisfied become less effective when judges reduce maintenance if the defendant argues his inability to pay the amount requested by the plaintiff.

Child maintenance assessment termed 'child support' is more advanced in Western countries. This is reflected in the policy and legal practice of the 34 countries of the Organization for Economic Cooperation and Development (OECD) ${ }^{13}$ such as the United States, Australia, the United Kingdom, Norway and Canada. ${ }^{14}$ For example,

10 “Siti Norzatulshima bt Abdullah vs Abdul Aziz bin Mat Hassan', Jurnal Hukum, vol. 42, no. 1 (2015), pp. 60-73.

11 "Sri Utama Dewi Kasman lwn Abu Bakar bin Abdullah", Jurnal Hukum, vol. 30, no. 1 (2010), pp. 111-29.

12 Ibid..

13 “OECD Family Database: the Family Support Calculator', OECD, http:// www.oecd.org/els/family/oecdfamilydatabasethefamilysupportcalculator.htm, accessed 28 Aug 2017.

${ }^{14}$ Ibid. 
the US state of Wisconsin ${ }^{15}$ determines child support in the form of a percentage - the Percentage Express Order (PEO). PEO is a percentage deducted before any tax or deduction from the gross income of a parent who does not live with the child and is also based on the number of children. The rate is set at $17 \%, 25 \%, 29 \%, 31 \%$ and $34 \%$ for one to five children, respectively. It is an advance on the previous approach practised before 1987 which was based on a fixed amount (fixed order) made by the courts. ${ }^{16}$

As well as the advance of child support assessment systems, studies discuss the negative impact of having set rates for child support, such as those by Daniel R. Meyer and Mei-Chun $\mathrm{Hu},{ }^{17}$ Kate Stirling and Tom Aldrich, ${ }^{18}$ Waller and Plotnick, ${ }^{19}$ and Judi Bartfeld and Irwin Garfinkel. For example, Waller and Plotnick ${ }^{20}$ found that most parents make their own financial agreements between ex-wives and ex-husbands rather than paying through a child support agency. This is because such agencies have the right to claim money paid to the children. Child support agencies have been found to excessively use their powers, with high rates being imposed on the payer without due consideration of their circumstances. Failure to pay a set amount is considered a criminal act and carries the threat of imprisonment. One cause why child support is ineffective is that it focuses more on parity between the amount of money and the obligations borne by the supporter and guardian living with the child rather than

15 Daniel R. Meyer et al., "Child Support Reform: Lessons from Wisconsin”, Family Relations, vol. 45, no. 1 (1996), p. 11.

${ }^{16}$ Judi Bartfeld and Irwin Garfinkel, "The Impact of Percentage-Expressed Child Support Orders on Payments", The Journal of Human Resources, vol. 31, no. 4 (1996), p. 794.

17 Daniel R. Meyer and Mei-Chen Hu, "A Note on the Antipoverty Effectiveness of Child Support among Mother-Only Families", The Journal of Human Resources, vol. 34, no. 1 (1999), pp. 225-34.

18 Kate Stirling and Tom Aldrich, "Child Support: Who Bears the Burden?", Family Relations, vol. 57, no. 3 (2008), p. 376.

19 Maureen R. Waller and Robert Plotnick, "Effective Child Support Policy for Low-Income Families: Evidence from Street Level Research", Journal of Policy Analysis and Management, vol. 20, no. 1 (2001), p. 89.

20 Ibid. 
focusing on the amount of money received by the child. ${ }^{21}$ Judi Bartfeld and Irwin Garfinkel argued that it is a big loss to the system if changes in a child support system result in children being more disadvantaged, even if many countries adopt it. ${ }^{22}$ Thus, it is still debatable if various child support systems are being best implemented. Nevertheless, child support systems do, to some extent, clearly help the maintenance of children who are abandoned or whose parents are separated. The benefit of the system is mostly in the higher payments by the payer, significantly lowering the risk of poor child health. ${ }^{23}$

Child support systems are different to Islamic maintenance law for children: child support is meant to ensure that all children gain support from their mother and father regardless of their mother's and father's marital status. The Parentage Act of the US state of Illinois states that it governs the rights and duties of parents who have never been married. It declares, "Illinois recognizes the right of every child to the physical, mental, emotional and monetary support of his or her parents" and that "[t]he parent and child relationship, including support obligations, extends equally to every child and to every parent, regardless of the marital status of the parents." (750 ILCS 45/1.1 (West 2014)), ${ }^{24}$

In Australia, for example, there is an issue between payers (mostly fathers) and guardians (mostly mothers who still need to pay some amount for child maintenance). Men's groups (payers) often assert that separated mothers deny fathers overnight stays with children to maximise the mothers' child support (so that the payer needs to pay more to the Child Support Agency) and social security benefits. By contrast, women's groups claim that separated fathers want more time with children to

21 Waller and Plotnick, "Effective Child Support Policy for Low-Income Families", p. 89; Meyer and Hu, "A Note on the Antipoverty Effectiveness of Child Support among Mother-Only Families”, pp. 225-34..

22 Bartfeld and Garfinkel, "The Impact of Percentage-Expressed Child Support Orders on Payments", p. 794.

23 Reagan A. Baughman, "The Impact of Child Support on Child Health", Review of Economics of the Household, vol. 15, no. 1 (2017), p. 794.

${ }^{24}$ In The Appellate Court of Illinois Second District, 2016 IL App (2d) 150291, no. 2-15-0291 (2016), https:// cases.justia.com/illinois/court-of-appeals-second-appellatedistrict/2016-2-15-0291.pdf?ts=1459372033, accessed 28 Aug 2019. 
reduce their child support liability. ${ }^{25}$

Child support systems which have been implemented mostly in OECD countries as described above ${ }^{26}$ have different implementations and interpretations than under shariah. In assessing The Working Draft of The Hague Convention on The International Recovery of Child Support and other Forms of Family Maintenance from a Malaysian shariah perspective, Zaleha Kamaruddin, Mohd Naim bin Haji Mokhtar, Siti Zalikhah Md. Nor noted several differences between the interpretation of this working draft and shariah.

The first is the recognition of parentage. Under shariah, parentage is established through marriage, acknowledgment or evidence. According to the shariah law of Malaysia, no paternity can be established for an illegitimate child. Apart from acknowledgement and evidence, paternity can only be established for children born within wedlock (marriage), while adoption is not considered a means of parentage. The establishment of a child's parentage is important as it creates certain rights and duties, such as fulfilling the maintenance of the child's food, clothing and lodging. ${ }^{27}$

However, there are also some differences in the implementation and ijtibad of the interpretation of parentage even between Muslim countries, such as with Indonesia and Malaysia. The Constitutional Court of Indonesia decided that the status of children born out of wedlock for religious courts in Indonesia is legal if the biological parents are married after childbirth. The decision is considered to accord with Tūfî's theory on maslabah (public interest). The decision is not dependent on the text of law (al-Quran and hadith) but prioritizes the maslahah. In the meantime, based on its Circular No. 7, 2012, the Supreme Court of Indonesia has instructed judges at religious courts that children born out of wedlock can be declared legitimate based on a judicial decree that the child's parents have married in accordance with Islamic law. This would enable children born in unregistered marriages to seek enforcement of support

25 See Bruce Smyth et al., "The Australian Child Support Reforms: A Critical Evaluation”, Australian Journal of Social Issues, vol. 50, no. 3 (2015), pp. 217-32.

26 Ibid.

27 Zaleha Kamaruddin, Mohd Naim Haji Mokhtar, and Siti Zalikhah Md Nor, "Assessing The Working Draft of The Hague Convention on The International Recovery of Child Support and Other Forms of Family Maintenance: Malaysian Syariah Perspective", Malaysian Journal of Shariah and Law, vol. 2 (2010), p. 103. 
and inheritance rights from their biological fathers. ${ }^{28}$ This decision differs from that of the Shariah Court of Malaysia that if the biological parents marry and the child is born within six month of the marriage date, then the child is considered illegitimate and born out of wedlock. This based on the position of all four Sunni schools that a child born within six months of the marriage is deemed to be illegitimate. ${ }^{29}$ The parentage in family law legislation states:

Ascription of paternity. ${ }^{30}$

Where a child is born to a woman who is married to a man more than six qamariah months from the date of the marriage or within four qamariah years after dissolution of the marriage either by the death of the man or by divorce, the woman not having remarried, the nasab or paternity of the child is established in the man, but the man, by way of li'an or imprecation, disavow or disclaim the child before the Court.

However according to Malaysian shariah law regarding payment of maintenance, even though a man is not accountable for maintaining his illegitimate children, he who adopts a child —including his own illegitimate child-is obligated to maintain that child. If he fails or neglects to pay maintenance, the court can make any necessary orders to ensure the welfare of the children. ${ }^{31}$ This can be found in Section 78. The duty to maintain a child accepted as a member of the family is in the same act. ${ }^{32}$

Thus, child support systems are more complicated in terms of policy and enforcement and cover a wide range of responsibilities, guidelines and interpretations. On the other hand, maintenance in Islam only orders the legal father and not the mother to support his

28 Muhamad Isna Wahyudi, 'Judges' Legal Reasoning on Child Protection: Analysis of Religious Courts Decisions on the Case of Child Parentage", Al-Jami'ah: Journal of Islamic Studies, vol. 55, no. 1 (2017), pp. 135-6.

29 Kamaruddin, Mokhtar, and Nor, "Assessing The Working Draft of The Hague Convention on The International Recovery of Child Support and Other Forms of Family Maintenance”, p. 103.

30 Islamic Family Law (Federal Territory), sec. 110.

31 Kamaruddin, Mokhtar, and Nor, "Assessing The Working Draft of The Hague Convention on The International Recovery of Child Support and Other Forms of Family Maintenance", p. 106.

32 Ibid. 
children regardless of whether the mother is working or is poor or rich. International research comprises discussions and debates conducive to the effective implementation of child support, particularly in terms of policy, parenting arrangements, the perception of fairness and child support compliance. ${ }^{33}$

It is critical to discuss the formula for adequate maintenance of a child not only in the Western world (where the term 'child support system' is frequently used) but also among Muslims. A strong formula will not only settle issues of fairness ${ }^{34}$ between parties but secure the health ${ }^{35}$ and living conditions of children.

In Malaysia, a policy similar to the child support programs in other countries is administered by the Family Support Division (BSK) of the Shariah Judiciary Department Malaysia (JKSM). ${ }^{36}$ The unit was officially established on October 22, 2008 to provide a platform for single mothers who were abandoned or divorced to gain interim maintenance for themselves and their children when the payer of maintenance neglects orders issued by the courts. This assistance is provided in the form of a loan and the payers of maintenance (husband) should explain the reasons for their neglect to the BSK. However, the BSK does not have a particular method for determining the maintenance required for a decent standard of living for wives and children. ${ }^{37}$ The amount of maintenance is determined by a judge in court. ${ }^{38}$

Hence, the BSK uses no special methods to determine the maintenance rate for a wife or child living in Malaysia, unlike OECD countries that enforce policies and special assessment formulas in

33 See Smyth et al., "The Australian Child Support Reforms", pp. 217-32.

34 Ibid.

35 Baughman found that higher payments of child support are associated with a greater chance of having private health insurance coverage and a significantly lowered risk of poor or declining health status. Baughman, "The Impact of Child Support on Child Health", p. 69.

36 Bahagian Sokongan Keluarga-BSK, https://www.facebook.com/ bahagiansokongankeluarga/, accessed 28 Aug 2017; "Laman Utama”, BSK Transit JKSM, http://bsktransit.jksm.gov.my/bsktransit/, accessed 28 Aug 2017.

37 Mohd. Haji Naim Mokhtar, Director of the Family Support Division in JKSM, telephone interview (21 Oct 2012).

38 Ibid. 
their child support systems. ${ }^{39}$ However, in an unpublished paper at the foundation of BSK, a committee tried to established a suitable method for determining how much the payer (father) should give to maintain his child. Among the suggestions is the implementation of a percentage rebate order according to the income of the father, beginning with an income of RM1000. Thus, percentage deductions by income of $23 \%$, $33 \%, 40 \%$ and $53 \%$ have been suggested for for first, second third and fourth child. However, this method has not yet been implemented in the BSK system in Malaysia. ${ }^{40}$ Among other suggestion was the obligation of maintaining the child not only by the payer but also by his heirs (such as the grandfather and uncle of the child on the father's side) if the father is incapable of supporting the child because of sickness, death or other acceptable causes determined by a court. ${ }^{41}$

\section{B. Determination of Ma'rüf and Kifäyab in the Maintenance of Children in Islam}

By a content analysis of the elements of ma'rüf and kifayah concerning child maintenance according to the interpretation of mufassirin, mubadittin and fuqaha, this study concludes the following.

\section{Elements of Ma'rüf}

There are four elements that need to be observed when determining the maintenance rate. The first is the socioeconomic standing of the father or payer. ${ }^{42}$ The second is the ability of the father to maintain his

39 This has been confirmed Mr. Mohd Zaid bin Mohd Noor, Assistant Shariah, Pt. Family Support, telephone interview (1 Sep 2020).

40 See Noraini Arifin, Noraini Mohd Hashim, and Roslina Che Soh, Pemahaman Cadangan Formula Pengiraan Nafkah (Bayu Beach Resort, Port Dickson, Negeri Sembilan, 29 Jun 2009). According to Dr Noraini Md Hashim, this formula has not been implimented by judges as there is no law or judiciary order which binds all judges to follow the formula. Dr Noraini Md Hashim, email interview (24 Jun 2015); Dr Noraini Md Hashim, email interview (2 Jul 2015).

41 Ibid

42 Muhyī al-Dīn Abī Zakariyyā Yahyā bin Syarf al-Nawawī, al-Majmū' Syarí alMuhaddhab, vol. 11 (Madinah: al-Maktabah al-Salafiyyah), p. 298; Abī Muḥammad ḥussain bin Mas'ūd bin Muḥammad al-Farā' al-Baghwī, al-Tahdhìb fì Figh Imām al-Syäfi'i, vol. 6, ed. by 'Ādil Aḥmad (Beirut: Dar al Kutub al-Ilmiyah, 1997), pp. 378-9; Muḥammad bin 
children. ${ }^{43}$ The third is the determination of the rates compatible with social customs and standards of living. ${ }^{44}$ The fourth is that maintenance be based on a child's real needs relative to age and his or her needs. ${ }^{45}$

\section{Elements of Kifäyah}

Determining the elements of kifayyah or adequate child maintenance should be made by standardising the basic needs of the poorer strata of society, needs according to socioeconomic class of society and also by the special needs of individuals, such as their health status. This is derived from the hadith of Hind, which states that a father or financier must at least meet the minimum requirements of the needs of children, which forms part of the basic meaning of kifäyah in child maintenance:

From Aisya RA, Hindun pledge a report to Prophet Muhammad (SAW) about Abu Sufyan (her husband) she said: "Abu Sufyan is such a stingy person, he did not give to me and my son what is enough for us except what I have taken from him secretly". Prophet Muhammad (SAW) then said, "Then take what is enough for you and your child in acceptable way (ma'rüf)." 46

Al-Juwaini describes the basic meaning of kifayah as the provision of maintenance that strengthens a child physically and preserves him from current or future harm. ${ }^{47}$ This indicates that kifäyah refers to both food and non-food items, such as lodging, clothing, medication, education

Aḥmad bin 'Umar al-Syātịī, al-Yāqūt al-Nafis fì Madhbab Ibn Idrìs, 2nd edition (Saudi: Dar al-Minhaj, 2007), p. 673; Muḥammad al-Zuhailī, al-Mu'tamad fi al-Fiqh al-Syafíí, vol. 4 (Damascus: Dar 'Ulūm, 2007), p. 289; Muḥammad Amīn ibn 'Umar Ibn 'Ābidīn, Hāshiyat Radd al-Muḅtār, vol. 1 (Misr: al-Bābī al-Halabī, 1966), p. 612.

43 Muḥammad ibn Aḥmad Qurțubī, al-Jämi li-Aḅkām al-Qứān, vol. 18 (Cairo: Maṭba'at Dār al-Kutub al-Mișrīyah, 1967), p. 172.

44 Muhammad al-Amīn bin Muhammad al-Shanqițī, Adwa' al-Bayan fi Idah al-Qur'an bi-al-Qur'an, vol. 8 (Beirut: Dar al-Fikr li al-Ṭibā'ah wa al-Nasyr wa al-Tauzì’, 1995), p. 216.

45 'Abd al-'Azīz Āmir, Al-Aíwāl Al-Syakhsiyyah (Cairo: Dar al-Fikr al-'Arabi), pp. 439-42.

46 Narrated by al-Bukhārī, Kitab al-Nafaqāt, Bab Khidmah al-Rajul fi Ahlihī, no. 5049, and Muslim, Kitab al-'Aqİiyah, Bab Qadiyyah Hindun, no. 1714.

47 'Abd al-Malik ibn 'Abd Allāh Imām al-Haramayn al-Juwaynī, Nihāyah al-Matlab fì Dirāyah al-Madhhab (Jeddah: Dār al-Minhāj, 2008), p. 515. 
and skills because all these are necessary for the healthy upbringing of a child that protects her from harm.

According to Abu Hanifah, the minimum adequacy of maintenance (adna kifäyab) can be determined in reference to the spending practices of the poorer strata of society in a country in the case of a wife's maintenance. ${ }^{48}$ Similarly, this study views that the minimum adequate rate of child maintenance also can be determined by referring to the requirements sufficient to meet the basic needs of children in the same strata of the community. Thus, a father is obliged to provide maintenance at or above the minimum level of adequacy for the poorer strata of society at that time and place. Consequently, a father should not provide a maintenance rate less the minimum requirement of adequacy, as it would harm basic sustainable living needs.

Fixing minimum levels of maintenance in child support should not prevent a child from receiving more support if the can father can afford it. This is based on the principle of feeding and clothing the family in accordance with social standards of food and dress according to the socioeconomic status of the father. However, if the father is so poor that he fails to provide the basic requirements needed by his children, the bare minimum requirements still must be met even with the help of a third party (the heirs of the father). Compliance with a minimum rates guarantees the basic needs of children to grow up and live righteously.

\section{Current Practices of Assessment of Child Maintenance in the Shariah Court and in Malaysian Society}

\section{Assessment of Child Maintenance in the Shariab Court of Malaysia}

This study conducted in-depth interviews with selected judges from shariah courts in Kuala Lumpur and Selangor. The nine selected are subordinate to the high shariah court depending on their location in urban and suburban districts of Kuala Lumpur and Selangor. These interviews

48 al-Shaykh Niz̄ām, al-Fatawa al-Hindiyah al-marufah bi-al-fatawa al-Alamkiriyah fi madhhab al-imam al-azam Abi Hanifah, vol. 1 (Dar al-Fikr, 1991), p. 570; Muhammad ibn Maḥmūd Akmal al-Din al-Babarti, al-Ināyah sharh al-Hidāyah, vol. 6 (Beirut: Dār al-Kutub al-'Ilmīyah, 2007), pp. 209-10; Abū Bakr ibn Mas'ūd Kāsānī, Badai al-Sanai fi Tartib al-Sharai, vol. 4 (Beirut: Dar al Kutub al-Ilmiyah, 1982), p. 25. 
occurred between September 2012 to May 2013. The honourable judges are; Yang Arif Tuan $\mathrm{Hj}$ Walid Abu Hassan ${ }^{49}$, Yang Arif Tuan Amran Mat $Z_{\text {Zin }}^{50}$, Yang Arif Tuan Fauzi Mokhtar ${ }^{51}$, Yang Arif Tuan Zainor Rasyid ${ }^{52}$, Tuan Kamarulzaman bin Ali ${ }^{53}$, Tuan Drs Atras bin Mohamad Zin ${ }^{54}$, Tuan Mohamad Fauzi bin Ismail ${ }^{55}$, Tuan Wan Mahyuddin Wan Muhammad ${ }^{56}$, and Tuan Shaiful Azli bin Jamaludin ${ }^{57}$.

In this interview process, data saturation was achieved when the researchers interviewed the seventh respondent. However, they increased the number of respondents to the eighth and ninth to test if themes or new ideas were raised. When the interview data of the ninth respondent still showed the same result, there was no need to interview more respondents on the same set question. Thus, the nine judges who were interviewed reached the saturation level of the desired data in the study. This also means that validity and reliability were achieved within the framework of the qualitative research.

The interviews with nine judges of the high and subordinate shariah courts of Malaysia found that they knew well that an assessment should be based on the elements of kifäyah and ma'rüf as discussed by Islamic scholars. However, from the standpoint of practicality, it appears

49 'Wilayah Persekutuan Shariah Court, Kuala Lumpur (High Court)', interview (3 May 2013).

50 'Wilayah Persekutuan Shariah Court, Kuala Lumpur (High Court)', interview (29 Mar 2013).

51 'Selangor Darul Ehsan Shariah High Court, Selangor', interview (14 Dec 2012).

52 'Selangor Darul Ehsan Shariah High Court, Selangor', interview (14 Dec 2012).

53 'Gombak Barat District Shariah Subordinate Court, Selangor', interview (14 Feb 2013).

54 'Hulu Langat District Shariah Subordinate Court, Selangor', interview (18 Feb 2013).

55 'Kuala Langat District Shariah Subordinate Court, Selangor', interview (14 Dec 2012).

56 'Petaling District Shariah Subordinate Court, Selangor', interview (18 Oct 2012).

57 'Gombak Timur District Shariah Subordinate Court, Selangor', interview (27 Sep 2012). 
that the kifäyah elements—a basic guarantee of adequacy — are not evident in the practice of the judges.

In some cases, court procedures took precedence over maintaining the basic needs of plaintiffs. For example, proving the levels they (wife or child) require, plaintiffs must submit evidence of daily and monthly expenses as evidence of the level of their financial needs, such as shopping receipts and bills. In some cases, the plaintiffs failed to provide such evidence to the court. Therefore, the judge had to postpone or provided an amount payable by the defendant ${ }^{58}$ which fell short of the criterion of kifäyah (adequacy) due to lack of evidence. Basic criteria have thus been overlooked in deciding the maintenance to be paid, although the judges did recognise the failure of the plaintiffs to provide evidence to the court regarding their monthly expenditures.

There has been no systematic evaluation of community practice for evaluating the element of ma'rüf by collecting price data on goods or services. This study found that, of the interviewed judges, only those from the Syaria High Court are assisted in determining the standards of community practice or the value of current goods. ${ }^{59}$ The results are only applicable to the judge concerned. Other judges interviewed, ${ }^{60}$ mostly in the Shariah Subordinate Court, made their own study by comparing the data obtained from mass media such as newspapers, internet and television and their own life experiences in determining the current cost of goods and services.

Thus, the study found that judges' consideration of the elements of kifäyah and ma'rüf needs to be more systematic, standardised and efficient to determine current costs in society as well as obtaining the cost of goods and services in the current market. The process also needs to be streamlined and understandable for judges to integrate into their judgments. Therefore, the study found the elements of ma'rüf and kifäyah in the practice of judges less than satisfactory.

58 Tuan Mohamad Fauzi bin Ismail, Tuan Shaiful Azli bin Jamaludin and Tuan Wan Mahyuddin Wan Muhammad

59 Yang Arif Tuan Haji Walid Abu Hassan dan Tuan Wan Mahyuddin Wan Muhammad.

${ }^{60}$ Please refer the list of the judges in the Shariah Subordinate Court 


\section{Current Practice of Society in Determining Child Maintenance Rates in Malaysia}

To investigate social spending, in-depth interviews were conducted with 26 wives with children of various ages and education to form an idea of the practices and daily expenses of their children, including for food, clothing, medicine, education and associated transport. These interviews were conducted from May to December 2013 within the Klang Valley, while a pilot study was conducted in April 2013 in Kuala Lumpur with different respondents from the real study.

Eligible respondents were identified for this study using purposive sampling. For this sample, characteristics such as being a mother who had at least one child were determined before respondents were selected. The study employed semi-structured interview questions. Each respondent was interviewed for two to three hours depending on the data and information they shared as well as their number of children. For example, the time allotted to interviewing respondents with five children was more than those with only one child. To assess the cost of such living expenses, the study categorised respondents into three socioeconomic classes: group respondent A (RA) for the B40 class (bottom 40\%, the lowest socio-economic class in Malaysia), group respondent $\mathrm{B}$ for the M40 class (medium 40\%, the middle socio-economic class in Malaysia) and group respondent $\mathrm{C}$ for the T20 class (top 20\%, the top socioeconomic class in Malaysia). This was according to household income based on the methodology of the Department of Statistics Malaysia (JPM) which divides household income in Malaysian society to the lowest 40\% (B-Bottom 40), 40\% medium (M-Medium) 40), and the highest $20 \%$ (T-Top) 20). ${ }^{61}$

In this study, the monthly household income of respondents is as follows. RA is the category of respondents with a household income of RM3400 and below; RB is the category of respondents with

61 Department of Statistics Malaysia, Report on Household Expenditure Survey 2009-2012 (Putrajaya: Department of Statistics Malaysia, 2012), p. 4. The methodology and the results of this study confirmed that the data coincides with the methodology applied by the Department of Statistics Malaysia through a series of email and telephone conversations May to December 2013, with Assist. Director, Price, Income and Expenditure, Statistics Division, Department of Statistics Malaysia. Mr. Azizul Abllah, email and telephone interview (Dec 2013). 
a household income of RM3401-RM10,000; RC is those respondents with a household income of RM10,001 and above. This is compatible and certified with the range of household income issued by the JPM for Indigenuos Malays in the Klang Valley of Malaysia. ${ }^{62}$ The study found that the basic needs of respondents' children were food and drink, clothing, shelter, medicine, tools and cleaning materials, and education. ${ }^{63}$ These items are the basic requirements needed for the respondents' children and are maintenance items recognised by law.

The calculations were based on the average amount of spending per month on each of the items in each group or class of respondents. The study found that the expenditure on basic requirements for the maintenance of respondents' children by age accordance to the respondents' class as shown in Table 1 below.

Table 1. The Kifayah (Adequate) Rate of Child Maintenance by Age for

62 The Klang Valley consists of the districts of Kuala Lumpur and Selangor;

${ }^{63}$ Kamaruddin, Mokhtar, and Nor, "Assessing The Working Draft of The Hague Convention on The International Recovery of Child Support and Other Forms of Family Maintenance" 
all Classes of Respondents ${ }^{64}$

\begin{tabular}{|c|c|c|c|c|c|c|c|c|c|c|c|c|c|c|c|}
\hline \multirow{2}{*}{$\begin{array}{l}\text { Item/Child } \\
\text { Respondent }\end{array}$} & \multicolumn{3}{|c|}{$\begin{array}{c}\text { Child aged } \\
\text { below } 4\end{array}$} & \multicolumn{3}{|c|}{ Child aged 4-6 } & \multicolumn{3}{|c|}{ Child aged $7-12$} & \multicolumn{3}{|c|}{$\begin{array}{c}\text { Child aged } 13- \\
17\end{array}$} & \multicolumn{3}{|c|}{$\begin{array}{c}\text { Child aged } 18 \\
\text { and over }\end{array}$} \\
\hline & $\mathbb{Z}$ & בิ & $\mathscr{U}$ & 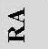 & בิ & $\mathscr{Z}$ & $\$$ & $\underline{\underline{z}}$ & $\mathscr{U}$ & $\geqq$ & בै & $\mathscr{Z}$ & $\mathbb{z}$ & בี & $\mathscr{Z}$ \\
\hline \multirow[b]{2}{*}{$\begin{array}{l}\text { Food \& Drink } \\
\text { /Milk }\end{array}$} & \multicolumn{15}{|c|}{ Amounts in Ringgit Malaysia (RM) } \\
\hline & 150 & 150 & 150 & 109 & 150 & 218 & 217 & 300 & 436 & 217 & 300 & 436 & $\mathrm{x}$ & $\mathrm{x}$ & $\mathrm{x}$ \\
\hline Clothing & 28 & 28 & 28 & 28 & 49 & 87 & 28 & 49 & 87 & 28 & 49 & 87 & $\mathrm{x}$ & $\mathrm{x}$ & $\mathrm{x}$ \\
\hline Hygine & 70 & 70 & 70 & 14 & 17 & 32 & 14 & 17 & 32 & 14 & 17 & 32 & $\mathrm{x}$ & $\mathrm{x}$ & $\mathrm{x}$ \\
\hline $\begin{array}{l}\text { Education (School } \\
\text { Fees and } \\
\text { Stationary) }\end{array}$ & $\mathrm{x}$ & $\mathrm{x}$ & $\mathrm{x}$ & 129 & 129 & 129 & 19 & 75 & 75 & 44 & 112 & 112 & $\mathrm{x}$ & $\mathrm{x}$ & $\mathrm{x}$ \\
\hline School Transport & $x$ & $\mathrm{x}$ & $\mathrm{x}$ & 60 & 60 & 60 & 60 & 60 & 60 & 60 & 60 & 60 & $\mathrm{x}$ & $\mathrm{x}$ & $\mathrm{x}$ \\
\hline $\begin{array}{l}\text { School pocket } \\
\text { money }\end{array}$ & $\mathrm{x}$ & $\mathrm{x}$ & $\mathrm{x}$ & $\mathrm{x}$ & $\mathrm{x}$ & $\mathrm{x}$ & 91 & 91 & 91 & 97 & 97 & 97 & 600 & 600 & 600 \\
\hline Childcare fee & 250 & 250 & 250 & $\mathrm{x}$ & $\mathrm{x}$ & $\mathrm{x}$ & $\mathrm{x}$ & $\mathrm{x}$ & $\mathrm{x}$ & $\mathrm{x}$ & $\mathrm{x}$ & $\mathrm{x}$ & $\mathrm{x}$ & $\mathrm{x}$ & $\mathrm{x}$ \\
\hline Total & 498 & 498 & 498 & 340 & 405 & 526 & 429 & 592 & 781 & 460 & 635 & 824 & 600 & 600 & 600 \\
\hline
\end{tabular}

The above table shows that the children's needs for maintenance varies according to age and socioeconomic category: spending is the highest for children from the T20 group (RC) followed by M40 (RB) and the lowest was B40 (RA). This is predictable because the highest income level households will usually select high quality goods and brands for their children and the poorest income households will select goods of a lower price that will meet with their purchasing power. This can be seen in food, drinks, clothing and hygiene.

Furthermore, children below four years old share the same cost of expenditure in formulated milk, clothes and hygiene. This is because most respondents, despite class, buy the same products: formulated milk, clothes and diapers (in hygiene category for their children). For example, for formulated milk, the classes of respondents share the same value of RM 150 per month for An-Mum, Dugro, Dupro, and Sustagien formulated milk, which can be categorized as a medium-cost formulated milk but is trusted in quality. It might be that respondents, regardless of their class, desire the best value in quality and money for formulated milk for their children.

${ }^{64}$ Source adapted from interviews, May to December 2013 
It is similar for childcare fees, which are mostly the same for children below four years across the classes, costing RM250 per month. This is because the rate of childcare is mostly the same in the Klang Valley when the study occurred-about RM250 monthly. For children aged 7-17 in primary and secondary schooling, the same amount of expenditure was found in all classes for school costs such as fees and stationary, school transportation and school pocket money. Respondents, despite their different socioeconomic classes, tend to choose public government schools, resulting in the same fees and related school costs spent on their children. For school fees, the respondents spent higher for kindergarten for children aged 4-6 years old. This is because the majority of respondents placed their children in private kindergarten as the chance of getting into public kindergartens is somewhat limited.

Children 18 and over shared same value of pocket money from their parents, about RM600 per month, across all socioeconomic groups in Malaysia. This pocket money is usually spent on food, topping up phone credit, toiletries and items related to student work such as binding and printing costs. All children above 18 in the study were furthering their study at college or university. The scholarship or loan that they usually received from the funding institution is for their spending in college, program fees and books, with some also having to support their daily expenses; these were mostly RA children in the lowest socioeconomic class.

The study determined food expenses per month of children for each age group. All expenses of children were gathered in the department interview with the respondens (the mother of the children) according to the ages and sosioeconomic classes equavalent to the statistic department of Malaysia (PTM) socio-economic divisons of B40, M40 and T20.

For food expenses, the study also referred to the Recommended Nutrient Intakes for Malaysians ${ }^{65}$, who suggessted by the Ministry of Health. According to Recommendation for energy requirement by life stages for Malaysians ${ }^{66}$,

65 "Research Priority Area 2: Monitoring of National Nutritional Status", in Recommended Nutrient Intakes for Malaysian: A Report of the Technical Working Group on Nutritional Guidelines (Putrajaya: National Coordinating Committee on Food and Nutrition, Ministry of Health Malaysia, 2005), p. 23.

66 Ibid. 
its recommended energy in kilocalories for female adults (which is the mothers of the children in this study, aged 30 to 59 ) is $2180 \mathrm{kcal}$. This is equavallent to the energy needed for an adolescent male aged 10-12 and adolescent females aged 13-15.

That is why the respondents (the mothers) claimed that their male and female children in primary and secondary school (aged 10-15 years old) were eating their amount of food. This claimed is supported by the above table where the kilocalories of energy required for female adults is equivalent to that of adolescent males and females, considering that the energy needed by a male adolescent might be more than their mother when they reach 13 and the energy required by female adolescents after age 15 might be gradually lower than their mothers according to the table. This study thus suggests that the amount of food needed by children may be equivalent to the mother. The majority of respondents who had children aged between four to six claimed that their children ate half the amount of food eaten by themselves. This is also supported by the $\mathrm{MOH}-\mathrm{RCNI}$ table that shows that the kilocalories needed for children aged 4-6 is $1340 \mathrm{kcal}$ for male children and $1290 \mathrm{kcal}$ for female children. These are equivalent to half of the $2180 \mathrm{kcal}$ of energy needed by the mothers. Thus, children aged between four and six can be estimated to need half the amount of food as their mothers, while children aged below four can be assumed to rely more on mothers' milk or formula than on normal food.

How were the hygeine expenses per month for children per age determined? Children aged four years and above consume the same hygiene products used by adults, such as body soap, detergent for laundy, toothpaste and shampoo. For children below four years old, the most important hygiene product identified throughtout the interviews with mothers was diapers. These are a very important requirement for children of this age who are usually not toilet-trained. Even if the mother is always home or spends all her time with her children, diapers are still an important requirement for these children for keeping them clean. This was confirmed in all interviews with all classes of mothers across all respondent groups. They make their choices of diaper brands on the market according to what is affordable to them, but not those which are really cheap-such diapers, according to some of the respondents, 
might irritate their children's skin. They thus did not compromise their children's safety and health, regardless of their socioeconomic class. The brands chosen by them (such as Drypers, Petpet and Huggist) cost about RM70 per month per child.

The study determined the cost of clothes per month for children per age? These might not be bought monthly, but expenses for clothing are taken from the total of a year, mostly at the beginning or end of the year, especially when buying school uniforms and during festival seasons. While most of the respondents did not buy clothes every month, they did buy them four to five times per annum for their children. Thus, the averange amount was divided by 12 months for ease of calculation and for determining the maintenance for clothing items for all children in the classes. The amount for clothing expenses differs across class, the upper class having higher normal expenses. However, for children below four years old, all classes shared the same clothing expenditure of RM28 per month.

The study determined the costs related to the education of children per age by applying some rules. The fee costs of primary and secondary schooling were determine only from data from government, not private, schools. This is because all respondents placed their children in government schools for primary and secondary education, despite their socioeconomic class.

For both kindergarten and tertiary education, the study found that all classes placed their children in both government and private institutions, even B40 (RA) respondents from the lowest socioeconomic class. Private kindergarten fees were still affordable for all respondents despite their class, and the intake for government kindergartens might have been limited in the research area. For tertiary education, the study found that most respondents' children received scholarships or loans from the National Funds of Education under government schemes such as PTPTN and MARA, even though they might have been enrolled in private Malaysian institutions. For tertiary education, the spending data of the children was only derived from respondents' children pursuing their education locally in Malaysia. Children studying abroad without relying on government loans were not covered in this study's calculation for tertiary education fees. 
The fees for secondary and primary schooling in this study were confimed through the fee structure from Sek Kebangsaan Bangsar for primary schools and Sekolah Menegah Kebangsaan Sri Pantai Kg. Kerinchi, Kuala Lumpur for secondary schools (as per the case study), amounting to an average fee of RM100 per year. This was also confirmed by respondents who were mothers of children in primary and secondary schooling. The fee structure and amount were also confirmed with the Deputy Director of the Office of Operation Sector in the Ministry of Education Malaysia. ${ }^{67}$

\section{E. Applying the Results of the Study to Determine the Rate of Child Maintenance in Shariah Courts in Malaysia}

The results of the study show that the rate of child maintenance differs across age and socio-economic class. The rate for adequate maintenance should align with children's needs and the ability of their fathers - kifäyah and ma'rüfin fiqh terms. If the father is unable to provide sufficient maintenance, he must then at least provide the basic needs of the child accordance to the lowest socioeconomic class (RA) in Malaysia.

The minimum rate of child maintenance proposed in this study was derived from the usual expenses of the poor or low-income groups, in line with the view of Abu Hanifah and the Hanafi' scholars for setting the minimum standard of kifäyah by analogy of meeting the basic level for maintaining one's wife in reference to the standards of a poor community. This, therefore, determines child maintenance. To determine the spending habits of the poorest section of Malaysian society, the study referred to the spending on respondents' children from the RA class (B40 class). The minimum maintenance rate for child maintenance is in Table 2 below.

${ }^{67}$ Mr Yong Abdullah, Chief Sector Operation Unit, Ministry of Education, interview (27 Mar 2014). 
Table 2. Proposed Minimum Rate of Child Maintenance ${ }^{68}$

\begin{tabular}{|c|c|c|c|c|c|}
\hline \multirow[b]{2}{*}{$\begin{array}{c}\text { Child Maintenance } \\
\text { Item }\end{array}$} & \multicolumn{5}{|c|}{ **(Category of Child and Maintenace Amounts (RM/Month } \\
\hline & $\begin{array}{l}\text { Ch i ld } \\
\text { a g e d } \\
\text { below } 4\end{array}$ & $\begin{array}{l}\text { Child } \\
\text { a g e d } \\
4-6\end{array}$ & $\begin{array}{c}\text { Child } \\
\text { a g e d } \\
7-12\end{array}$ & $\begin{array}{l}\text { Child } \\
\text { a ged } \\
13-17\end{array}$ & $\begin{array}{l}C h \text { i } 1 \mathrm{~d} \\
\text { a } g \text { e d } \\
18 \text { and } \\
\text { over }\end{array}$ \\
\hline $\begin{array}{l}\text { Food \& drink / } \\
\text { milk }\end{array}$ & $150^{* *}$ & 109 & 217 & 217 & $\mathrm{X}$ \\
\hline Clothing & 28 & 28 & 28 & 28 & $\mathrm{X}$ \\
\hline Hygine & 70 & 14 & 14 & 14 & $\mathrm{X}$ \\
\hline $\begin{array}{l}\text { Education (school } \\
\text { Fees and statio- } \\
\text { (nery }\end{array}$ & $\mathrm{X}$ & 129 & 19 & 44 & $\mathrm{X}$ \\
\hline School transport & $\mathrm{X}$ & 60 & 60 & 60 & $\mathrm{X}$ \\
\hline $\begin{array}{l}\text { School pocket } \\
\text { money }\end{array}$ & $\mathrm{X}$ & $\mathrm{X}$ & 91 & 97 & 600 \\
\hline Childcare fees & 250 & $\mathrm{X}$ & $\mathrm{X}$ & $\mathrm{X}$ & $\mathrm{X}$ \\
\hline Total & $498 *$ & 340 & 429 & 460 & 600 \\
\hline
\end{tabular}

This table shows the living habits of children based on respondent group RA, the lowest basic wage group in Kuala Lumpur and Selangor. In securing the minimum rate of child maintenance, the rate suggested in the table should form guidelines for judges to not determine less than these amounts. This is because the amount suggested is the minimum rate of kifäyah (need) based on a current study of society and also of ma'rü as the determination of the rate based not only on current market prices but also according to the real consumption expenses in society.

68 This amount includes the cost of childcare fees which the mother may need because she works outside the home to maintain herself and her children; the father then needs to pay the childcare fee to the mother. Source: Adapted from the interviews, from May to December 2013 
With the data suggested by this study, judges should find it easier determining rates for basic living based on the assessment of current economic realities and community practice. Judges can also identify items that comprise the most basic child maintenance that should be considered, such as food, clothing, hygiene, education and transportation to school. These basic items for society are determined not only from the interview data but also that accepted by law (Family Law Act/Enactment of Malaysia), as well as according to fiqhi interpretation and discussion. With the data from the current socioeconomic study, judges should be able to form a clearer view of the basic criteria of kifäyah and ma'rüf and help ensure these are met when determining child maintenance rates in court.

Based on this study method, a periodical study can be made to determine household expenses in Malaysian Muslim society for children every five years, perhaps by the Statistics Department of Malaysia. This can form a guideline for periodically updating the rate of basic maintenance for children in this country. However, judges may not rely fully on the report of Malaysia household expenses because, while food items and clothing are covered in the report, it is not exactly in accordance to with shariah because it includes other item such as alcoholic drinks and some other items which are not suitable as maintenance items. The report data also covers Muslim and non-Muslim households in Malaysia and not just the Muslim community. The calculations are also based on expenses per household and not per individual or ages.

Thus, the data cannot be compared exactly in determining the minimum rate of child maintenance accordance to shariah. The study consequently suggests a periodical study be conducted for the purpose of obtaining real rates of maintenance practised in Muslim society, especially for wives and children. Hence, only the rate of kifäyah and ma'rüf of child maintenance can be determined.

To ensure that the rate of kifäyah and ma'rüf of child maintenance accords more with reality, shariah suggests a back-up plan if a father fails to provide such an amount because of allowable circumstances such as sickness, imprisonment or death. Thus, the amount of child maintenance should be guaranteed by the heirs of the father such as his father (if still alive and can afford it) or his male siblings according to their fulfilment 
of conditions assigned by shariah. ${ }^{69}$ Thus, determining the basic rate of kifäyah and ma'rüf of child maintenance is not a fantasy but a reality that can be planned accordingly.

\section{F. Concluding Remarks}

As an assessment method, the child support systems adopted by OECD countries $^{70}$ have experienced a shift from traditional methods or fixed rates set by courts to assessment methods based on parental income as percentages. ${ }^{71}$ After implementation, this system appears to overlook the payer's financial standing and the real needs of children. Thus methods of assessment are required based on the real needs of children. $^{72}$

The method set forth in the study, although similar, differs in its assessment of adequacy in accordance with shariah. It is based on the views expressed by Imam Abu Hanifah to meet the minimum criterion of sufficiency (kifäyah), where reference should be made to the maintenance needs of the poor. These were highlighted by the study not as those who go hungry or cannot clothe themselves but in reference to low-income

69 Siti Nur Hazimah Hamid et al., 'Pembiayaan Nafkah Anak Yatim: Tinjauan Menurut Perspektif Fiqh, Undang-Undang Keluarga Islam Malaysia Serta Kefahaman dan Amalan Masyarakat (Financing Orphans: An Overview from Fiqh Perspective, Islamic Family Law Enactment of Malaysia and Its Level of Understandings and Practices among Malaysian Muslims)', Akademika, vol. 90, no. 1 (2020), pp. 140-1.

70 .'Child Support Handbook', Office of Child Support Enforcement, https://www. acf.hhs.gov/css/resource/handbook-on-child-support-enforcement, accessed 28 Aug 2019; 'OECD Family Database: the Family Support Calculator'.

71 For example, for Wisconsin, United States, implementing the Child Support Assurance System (CSAS) in 1987, see Daniel R. Meyer et al., 'Child Support Reform: Lessons from Wisconsin', Family Relations, vol. 45, no. 1 (1996), p. 11. A deduction system based on a percentage of parents' income was also practised in Norway in the 1990s, see Anne Skevik, 'Fairness in Child Support Assessments: The Views of Nonresident Fathers in Norway', International Journal of Law, Policy and the Family, vol. 20, no. 2 (Oxford Academic, 2006), pp. 181-200.

${ }^{72}$ For example, in Norway, see Anne Skevik, Skevik, 'Fairness in Child Support Assessments'. In Australia and the United Kingdom, see Belinda Fehlberg and Mavis Maclean, 'Child Support Policy in Australia and the United Kingdom: Changing Priorities But A Similar Tough Deal for Children?', International Journal of Law, Policy and the Family, vol. 23, no. 1 (Oxford Academic, 2009), pp. 1-24. and 'Child Support Handbook'. the Child Support Handbook (OCS), 
Bahiyah Ahmad et al.

groups, which in Malaysia's case is the B40 socioeconomic group.

The determination of the minimum wage to maintain children meets the requirements of the objective of shariah of preserving soul, mind, religion, wealth and progeny. Furthermore, the socioeconomic demands of society must also be regularly assessed. Such a systematic determination of maintenance and living standards will assist judges to determine maintenance that is appropriate to current customs and ensure the well-being of all parties. 
Assessing the Rate of Child Maintenance (Financial Support)

\section{BIBLIOGRAPHY}

Ahmad, Bahiyah, "Penentuan Kriteria Kifayah dan Ma'ruf Nafkah Isteri dan Anak di Malaysia", PhD. Dissertation, Kuala Lumpur: University of Malaya, 2015.

Āmir, 'Abd al-'Azīz, Al-AÍwāl Al-Syakbsiyyah, Cairo: Dar al-Fikr al-'Arabi.

Arifin, Noraini, Noraini Mohd Hashim, and Roslina Che Soh, Pemahaman Cadangan Formula Pengiraan Nafkeah, Bayu Beach Resort, Port Dickson, Negeri Sembilan, 29 Jun 2009.

al-Babarti, Muḥammad ibn Maḥmūd Akmal al-Din, al-Ināyah Sharh alHidàyah, vol. 6, Beirut: Dār al-Kutub al-'Ilmìyah, 2007.

Bahagian Sokongan Keluarga-BSK, https://www.facebook.com/ bahagiansokongankeluarga/, accessed 28 Aug 2017.

Bartfeld, Judi and Irwin Garfinkel, "The Impact of Percentage-Expressed Child Support Orders on Payments", The Journal of Human Resources, vol. 31, no. 4, 1996, pp. 794-815 [https://doi.org/10.2307/146147].

Baughman, Reagan A., "The Impact of Child Support on Child Health", Review of Economics of the Household, vol. 15, no. 1, 2017, pp. 69-91 [https://doi.org/10.1007/s11150-014-9268-3].

al-Bukhārī, Muhammad bin Ismā̄̄il, Abū 'Abd Allāh, "Șahịị al-Bukhārì”, in al-Jami' al-Sabih al-Mukhtasar, vol. 5, 3rd edition, ed. by Mușțafā Dīb al-Bughā, Beirut: Dar ibn Kathir, 1987.

"Child Support Handbook", Office of Child Support Enforcement, https:// www.acf.hhs.gov/css/resource/handbook-on-child-supportenforcement, accessed 28 Aug 2019.

Department of Statistics Malaysia, Report on Household Expenditure Survey 2009-2012, Putrajaya: Department of Statistics Malaysia, 2012.

Fehlberg, Belinda and Mavis Maclean, "Child Support Policy in Australia and the United Kingdom: Changing Priorities But A Similar Tough Deal for Children?", International Journal of Law, Policy and the Family, vol. 23, no. 1, Oxford Academic, 2009, pp. 1-24 [https://doi. org/10.1093/lawfam/ebn015].

Hamid, Siti Nur Hazimah et al., "Pembiayaan Nafkah Anak Yatim: Tinjauan Menurut Perspektif Fiqh, Undang-Undang Keluarga Islam 
Bahiyah Ahmad et al.

Malaysia Serta Kefahaman dan Amalan Masyarakat. (Financing Orphans: An Overview from Figh Perspective, Islamic Family Law Enactment of Malaysia and Its Level of Understandings and Practices among Malaysian Muslims)", Akademika, vol. 90, no. 1, 2020, pp. 137-49.

In The Appellate Court of Illinois Second District, 2016 IL App (2d) 150291, no. 2-15-0291, 2016, https:// cases.justia.com/illinois/court-of-appealssecond-appellate-district/2016-2-15-0291.pdf?ts=1459372033, accessed 28 Aug 2019.

Islamic Family Law (Federal Territory), http://www2.esyariah.gov.my/ esyariah/mal/portalv1/enakmen2011/Eng_act_lib.nsf/b3ac9c21 8c8efdc4482568310022d8b3/86ecb41a724cb751482569810025f1 6a?OpenDocument, accessed 14 Apr 2020.

al-Juwaynī, 'Abd al-Malik ibn 'Abd Allāh Imām al-Ḥaramayn, Nihāyah al-Matlab fì Dirāyah al-Madhbab, Jeddah: Dār al-Minhāj, 2008.

Kamaruddin, Zaleha, Mohd Naim Haji Mokhtar, and Siti Zalikhah Md Nor, "Assessing The Working Draft of The Hague Convention on The International Recovery of Child Support and Other Forms of Family Maintenance: Malaysian Syariah Perspective", Malaysian Journal of Shariah and Law, vol. 2, 2010.

Kāsānī, Abū Bakr ibn Mas'ūd, Badai al-Sanai fi Tartib al-Sharai, vol. 4, Beirut: Dar al Kutub al-Ilmiyah, 1982.

"Laman Utama”, BSK Transit JKSM, http://bsktransit.jksm.gov.my/ bsktransit/, accessed 28 Aug 2017.

Meyer, Daniel R. et al., "Child Support Reform: Lessons from Wisconsin”, Family Relations, vol. 45, no. 1, 1996, pp. 11-8 [https:// doi.org/10.2307/584765].

Meyer, Daniel R. and Mei-Chen Hu, "A Note on the Antipoverty Effectiveness of Child Support among Mother-Only Families", The Journal of Human Resources, vol. 34, no. 1, 1999, pp. 225-34 [https:// doi.org/10.2307/146309].

al-Naisābūrī, Muslim bin Hajjāì Abū al-Hussain al-Qusyairi, Șą̧ị̧ Muslim, vol. 2, ed. by Muḥammad Fu'ad 'Abd al-Bāqī, Beirut: Dar Ihya alTurath al-'Arabi, 2012. 
Niz̄ām, al-Shaykh, al-Fatawa al-Hindiyah al-marufah bi-al-fatawa al-Alamkiriyah fi madhhab al-imam al-azam Abi Hanifah, vol. 1, Dar al-Fikr, 1991.

"OECD Family Database: the Family Support Calculator", OECD, http:// www.oecd.org/els/family/ oecdfamilydatabasethefamilysupportcalculator.htm, accessed 28 Aug 2017.

Qurțubī, Muḥammad ibn Aḥmad, al-Jämi‘ li-Aḅkām al-Qur'ān, vol. 18, Cairo: Mațba'at Dār al-Kutub al-Mișrīyah, 1967.

"Research Priority Area 2: Monitoring of National Nutritional Status", Recommended Nutrient Intakes for Malaysian: A Report of the Technical Working Group on Nutritional Guidelines, Putrajaya: National Coordinating Committee on Food and Nutrition, Ministry of Health Malaysia, 2005.

"Sarah binti Hamzah vs Adam Stanislaw Naglik@ Adam bin Abdullah", Jurnal Hukum, vol. 46, no. 1, 2018.

al-Shanqițī, Muhammad al-Amīn bin Muhammad, Adwa' al-Bayan fi Idah al-Qur'an bi-al-Qur'an, vol. 8, Beirut: Dar al-Fikr li al-Ṭibā'ah wa alNasyr wa al-Tauz $\overrightarrow{1}, 1995$.

"Siti Norzatulshima bt Abdullah vs Abdul Aziz bin Mat Hassan", Jurnal Hukum, vol. 42, no. 1, 2015.

Skevik, Anne, "Fairness in Child Support Assessments: The Views of Non-resident Fathers in Norway", International Journal of Law, Policy and the Family, vol. 20, no. 2, Oxford Academic, 2006, pp. 181-200 [https://doi.org/10.1093/lawfam/ebl012].

Smyth, Bruce et al., "The Australian Child Support Reforms: A Critical Evaluation", Australian Journal of Social Issues, vol. 50, no. 3, 2015, pp. 217-32 [https://doi.org/10.1002/j.1839-4655.2015.tb00347.x].

"Sri Utama Dewi Kasman lwn Abu Bakar bin Abdullah", Jurnal Hukum, vol. 30, no. 1, 2010.

Stirling, Kate and Tom Aldrich, "Child Support: Who Bears the Burden?", Family Relations, vol. 57, no. 3, 2008, pp. 376-89.

Wahyudi, Muhamad Isna, “Judges’ Legal Reasoning on Child Protection: Analysis of Religious Courts' Decisions on the Case of Child Parentage", Al-Jami'ab: Journal of Islamic Studies, vol. 55, no. 1, 2017, 
Bahiyah Ahmad et al.

pp. 127-54 [https://doi.org/10.14421/ajis.2017.551.127-154].

Waller, Maureen R. and Robert Plotnick, "Effective Child Support Policy for Low-Income Families: Evidence from Street Level Research", Journal of Policy Analysis and Management, vol. 20, no. 1, 2001, pp. 89-110. 